\title{
The Fate of Amylase Introduced into the Body of Warm-Blooded Animals.
}

On the Relation between the Diastase Preparations Containing the Amylolytic Ferment Given per Os or Hypodermically and Its Amount Excreted in the Urine, Proportionate to That in the Blood-Serum; and Also the Facts Observed in the Course of These Experiments Concerning the Blood-Sugar Content.

Br

YOSHIBUMI MASUMIZU.

(From Prof. T. Kumagai's Medical Clinic, Toholu Imperial University, Sendai.)

The diastatic ferment in the urine has long been studied since Cohnheim ${ }^{1)}$ in 1863 observed its presence in the urine. Mage $\mathrm{n} \mathrm{i} \mathrm{e}^{2)}$ in 1846 proved the human blood to be amylolytic. Although the ferment was known to be present, its study made little progress until $\mathrm{Wohlg} \mathrm{e} \mathrm{muth} \mathrm{h}^{3)}$ in 1908 succeeded in estimating accurately this ferment.

W o h l g e m u t h, ${ }^{4)}$ after the ligation of the duct of the pancreas in a dog, found both in the urine and the blood an increased amount of the ferment, which, however, very rapidly became normal again. In $1909^{5)}$ he found in four cases of kidney disease and two cases of diabetes a little decrease of diastatic content in the urine.

$\mathrm{Benczur},{ }^{6)}$ following Wohlgemuth's original method, examined the serum and urine of fifty cases and discovered that there was no change in the value of the diastatic content. In one case of occlusion of the pancreatic duct, however, he found a diastatic content much exceeding normal, and he also found a high content in nine out of sixteen cases of nephistis.

On the other hand, $\mathrm{y} \mathrm{n} \mathrm{ha} \mathrm{u} \mathrm{s} \mathrm{e} \mathrm{n}^{7)}$ in 1910 found in the urine of forty diabetics and thirty-two cases of nephritis a large decrease in diastatic content. Kosenthal ${ }^{8)}$ in 1911, using the modified Wohlgemuth method, found the decreased diastatic ferment of the urine in seven cases of chronic parenchymatous nephritis. 
M a r i n $0^{93}$ in 1911, following a modified method of his own, found a great decrease in diastatic ferment of the urine in nephritis.

$\mathrm{L}$ o e pe $\mathrm{r}$ and $\mathrm{F}$ i c a $i,{ }^{10)} 1907$, after ligating the Wi r s u $\mathrm{ng}$ duct of a dog, found, both in the urine and the blood, a decreased amount of the ferment.

In another field, $\mathrm{Ku} \mathrm{s} \mathrm{maul} \mathrm{l}^{11)}$ in 1874 tried to use diastase preparations in the medical treatment of diabetics. Although he hypodermically injected the diastase preparation, he found no change in the blood and in the urine. But he succeeded in decreasing the elimination of sugar in the urine by means of the intravenous injection of a lesser quantity of the same substance.

So it will be interesting to investigate the value of the diastatic content of the blood and the urine after the diastase preparations are given both per os and injected hypodermically.

\section{Method.}

The substratum used consisted of a 1 per 1000 solution of soluble starch, the starch being $\mathrm{K}$ a h l b a u m's special "Lösliche Stärke." The amount of this $(0.1 \mathrm{grm}$.) was weighed out and 100 c.c. of distilled water were added. The suspension was heated to boiling and kept boiling for fifteen minutes with stirring. The solution was then allowed to cool, and distilled water was added in order to make it up to 100 c.c. For safety a fresh solution was prepared daily. When urine was to be examined, the urine passed in the twenty-four hours was collected and the amylase content of the day's mixed specimen was determined. The product of this value and the volume of urine passed gave the total amount of amylase passed each day. So from the above specimen each definite quantity of urine was pipetted into a series of test tubes, in decreasing quantities.

To each tube 2 c.c. of the starch solution were then added; the tubes were mixed by shaking and were placed in a water-bath at $38^{\circ}$ C.; at the end of thirty minutes the tubes were removed from the bath and were plunged into cold water to arrest digestion. Upon adding a few drops of L u g o l's solution to each tube a beautiful graduation of color was produced. The tubes in which no blue color is seen at all are naturally free from starch, whereas those colored purple show the presence of this substance. That tube which stands at the lowest in the non-blue set and at the same time next to the first purple one 
is taken as the limit ("Limes"); that is to say, it contains just enough amylolytic ferment to change 2 c.c. of $1 / 1000$ starch solution.

Reduction to units is done as follows: $\mathrm{X}=$ number of c.c. of urine required to digest 2 c.c. of starch solution $(1: 1000)$ in thirty minutes at $38^{\circ} \mathrm{C} . \quad \mathrm{D}_{30^{\prime}}^{38^{\circ}}=$ number of amylolytic units per c.c. of urine, determined under these conditions. Then $\mathrm{D}_{30^{\circ}}^{3 \mathrm{~s}^{\circ}}=\frac{2}{\mathrm{x}}$.

The method I used for the determination of the amylase value of blood-serum was the same as that used for urine, aside from using normal saline solution in place of distilled water. The solution given per os consisted of 5 grms. of these preparations in 50 c.c. of ordinary water. 2 c.c. of 1 per cent of the diastase preparations were hypodermically injected. The "Taka-diastase" is made by S a n k y o \& Co. of Tokyo and "pancreatin" by Parke, Davis \& Co.

The blood-sugar content was estimated after $\mathrm{B}$ a $\mathrm{n}$ g by puncture of the ear-lobe every morning.

\section{Normal Amylase Content of Blood-Serum and Urine.}

As to the amount present in the serum of normal rabbits $I$ have found it to be constant, viz. $\mathrm{D}=8$ units. In the urine of normal rabbits a value of from 4 to 32 units per c.c. has been found the average, though in the case of urine more variation might be expected than in the serum.

\section{Experimental Results.}

The following experiments were carried out with a view to testing the influence of the concentration of the urine on the value of $\mathrm{D}_{30^{\prime}}^{38^{\circ}}$ per c.c. To test this point further I took two rabbits, collected the urine passed in twenty-four hours on five successive days in each case, and determined the amylase content of the day's mixed specimen and also occasionally that ferment of the blood-serum of the rabbit. From the sixth day an artificial diuresis was produced by giving the rabbit 50 c.c. of ordinary water.

The difference between the diastatic ferment in the urine for five days before and after giving ordinary water was $2150-2020=130$, the amount of diastatic ferment in the urine being increased (Table I).

The difference between the total diastatic ferment in the urine for five days before and after giving ordinary water was $2470-2328=$ 142 , the amount of diastatic ferment in the urine being increased (Table II). 
TABLE 1 .

Experiment I. Normal rabbit. 1.83 kilos.

\begin{tabular}{|c|c|c|c|c|}
\hline Date & $\mathrm{D}_{30^{\prime}}^{30^{\circ}}$ & $\begin{array}{c}\text { Volume of urine } \\
\text { c.c. }\end{array}$ & Total $\mathrm{D}_{30^{\prime}}^{38^{\circ}}$ & $\begin{array}{l}\text { Total amount of } \\
\mathrm{D}_{30^{\prime}}^{38^{\circ}} \text { for } 5 \text { days }\end{array}$ \\
\hline $\begin{array}{c}\text { Sept., } 1922 \\
5 \\
6 \\
7 \\
8 \\
9\end{array}$ & $\begin{array}{l}4 \\
4 \\
4 \\
4 \\
4\end{array}$ & $\begin{array}{r}40 \\
95 \\
100 \\
100 \\
170\end{array}$ & $\begin{array}{l}160 \\
380 \\
400 \\
400 \\
680\end{array}$ & 2020 \\
\hline \multicolumn{5}{|c|}{ After giving 50 c.c. of ordinary water. } \\
\hline $\begin{array}{l}12 \\
13 \\
14 \\
15 \\
16\end{array}$ & $\begin{array}{l}2 \\
4 \\
2 \\
4 \\
2\end{array}$ & \begin{tabular}{|l|}
155 \\
165 \\
140 \\
150 \\
150
\end{tabular} & $\begin{array}{l}310 \\
660 \\
280 \\
600 \\
300\end{array}$ & 2150 \\
\hline
\end{tabular}

TABLE II.

Experiment II. Normal rabbit. 1.8 kilos.

\begin{tabular}{|c|c|c|c|c|}
\hline Date & $\mathrm{D}_{30^{\prime}}^{38^{\circ}}$ & $\begin{array}{c}\text { Volume of urine } \\
\text { c.c. }\end{array}$ & Total $\mathrm{D}_{30^{\prime}}^{38^{\circ}}$ & $\begin{array}{l}\text { Total amount of } \\
\mathrm{D}_{30^{\prime}}^{38^{\circ}} \text { for } 5 \text { days }\end{array}$ \\
\hline $\begin{array}{c}\text { Sept., } 1922 \\
5 \\
6 \\
7 \\
8 \\
9\end{array}$ & $\begin{array}{l}4 \\
4 \\
4 \\
4 \\
4\end{array}$ & $\begin{array}{r}67 \\
145 \\
110 \\
180 \\
80\end{array}$ & $\begin{array}{l}268 \\
580 \\
440 \\
720 \\
320\end{array}$ & 2328 \\
\hline \multicolumn{5}{|c|}{ After giving 50 c.c. of water. } \\
\hline $\begin{array}{l}12 \\
13 \\
14 \\
15 \\
16\end{array}$ & $\begin{array}{l}2 \\
4 \\
2 \\
4 \\
2\end{array}$ & \begin{tabular}{|l|}
150 \\
155 \\
155 \\
160 \\
200
\end{tabular} & $\begin{array}{l}300 \\
620 \\
310 \\
640 \\
400\end{array}$ & 2470 \\
\hline
\end{tabular}

While the urine volume increases, as with the two rabbits in Experiments I and II, after giving water $\mathrm{D}$ tends to decrease inversely.

After all, the total amount of amylase for five days before giving 50 c.c. of water is almost the same as that following it. We now proceed to experiments in which diastase preparations were given per os and hypodermically. The amylolytic power of the diastase preparation is shown in Table III.

TABLE III.

\begin{tabular}{|c|c|c|c|c|}
\hline $\mathrm{D}_{30^{\prime}}^{38^{\circ}}$ & of 1 c.c. of & 1 per & of taka-diastase & \\
\hline “ & " $"$ " & 10 & "pancreatin & \\
\hline “" & " & 10 & "taka-diastase & \\
\hline “ & "4 & 10 & "pancreatin & \\
\hline
\end{tabular}


The diastatic ferment in the daily urine was determined on five or ten successive days; occasionally that of the blood-serum and the blood-sugar content of the rabbit were also estimated before giving the diastatic preparation.

Ex p e r i m e n t III. Normal rabbit. 1.79 kilos.

We determined the amylolytic power of the urine for five days and then gave per os 5 grms. of taka-diastase dissolved in 50 c.c. of water to find out the amylolytic power of the urine (Table IV).

TABLE IV.

\begin{tabular}{|c|c|c|c|c|c|}
\hline \multirow[b]{2}{*}{ Date } & \multicolumn{4}{|c|}{ Urine } & \multirow{2}{*}{$\frac{\text { Blood }}{\mathrm{D}_{30^{\prime}}^{38^{\circ}}}$} \\
\hline & $\mathrm{D}_{30^{\prime}}^{38^{\circ}}$ & $\begin{array}{c}\text { Volume } \\
\text { c.e. }\end{array}$ & $\begin{array}{r}\text { Total } \\
\mathrm{D}_{30^{\prime}}^{38^{\circ}}\end{array}$ & $\begin{array}{l}\text { Total amount of } \\
\mathrm{D} \text { for } 5 \text { days }\end{array}$ & \\
\hline $\begin{array}{c}\text { April, } 1922 \\
14 \\
15 \\
16 \\
17 \\
18\end{array}$ & $\begin{array}{l}8 \\
4 \\
4 \\
4 \\
4\end{array}$ & $\begin{array}{l}160 \\
140 \\
150 \\
145 \\
150\end{array}$ & $\begin{array}{r}1280 \\
560 \\
600 \\
580 \\
600\end{array}$ & 3620 & 8 \\
\hline $\begin{array}{l}20 \\
21 \\
22 \\
23 \\
24\end{array}$ & $\begin{array}{r}4 \\
16 \\
8 \\
8 \\
8\end{array}$ & $\begin{array}{c}\text { giving ta } \\
180 \\
90 \\
250 \\
200 \\
210\end{array}$ & $\begin{array}{c}\text { astase } p \\
720 \\
1440 \\
2000 \\
1600 \\
1680\end{array}$ & 7440 & 8 \\
\hline
\end{tabular}

The difference between the total diastatic ferment in the urine for five days before and after giving taka-diastase was 3820 , the amount of diastatic ferment in the urine being increased. The total amount of the diastatic ferment of the taka-diastase given per os for five days was 6250 .

So we concluded that about half of the diastatic value given per os was excreted in the urine in five days.

Experiment IV. Normal rabbit. 1.75 kilos.

Five grms. of taka-diastase dissolved in 50 c.c. of water were given per os to the rabbit five successive days, and the amylolytic power of the urine and the blood-sugar was determined (Table V).

The difference between the total diastatic ferment in the urine for five days before and after giving taka-diastase was 7080, the amount of diastatic ferment in the urine being increased. The total amount of the diastatic ferment of taka-diastase given per os for five days was 6250 .

It will be seen that almost the total amount of the diastatic value given per os was excreted in the urine in five days; or rather some- 
what more is excreted than is given per os. This may be explained by the fact that the diastase in the urine is in a more favorable medium. The blood-sugar is almost unchanged.

TABLE V.

\begin{tabular}{|c|c|c|c|c|c|c|}
\hline \multirow[b]{2}{*}{ Date } & \multicolumn{4}{|c|}{ Urine } & \multicolumn{2}{|c|}{ Blood } \\
\hline & $\mathrm{D}_{30^{\prime}}^{38^{\circ}}$ & $\begin{array}{c}\text { Volume } \\
\text { c.c. }\end{array}$ & $\begin{array}{c}\text { Total } \\
\mathrm{D}_{30^{\prime}}^{38^{\circ}}\end{array}$ & $\begin{array}{c}\text { Total amount of } \\
D \text { for } 5 \text { days }\end{array}$ & $\mathrm{D}_{30^{\prime}}^{38^{\circ}}$ & $\underset{C}{\text { Sugar }}$ \\
\hline $\begin{array}{c}\text { March, } 1922 \\
31 \\
\text { April } \\
1 \\
2 \\
3 \\
4\end{array}$ & $\begin{array}{l}8 \\
4 \\
8 \\
4\end{array}$ & $\begin{array}{l}180 \\
200 \\
190 \\
170 \\
120\end{array}$ & $\begin{array}{r}1440 \\
1600 \\
760 \\
1360 \\
480\end{array}$ & 5640 & 8 & 0.098 \\
\hline $\begin{array}{l}5 \\
6 \\
7 \\
8 \\
0\end{array}$ & $\begin{array}{r}16 \\
16 \\
16 \\
16\end{array}$ & $\begin{array}{l}\text { After giv } \\
210 \\
170 \\
140 \\
200\end{array}$ & $\begin{array}{l}\text { taka-d } \\
3360 \\
2720 \\
2240 \\
3200\end{array}$ & stase per os. & & \\
\hline 9 & 8 & 150 & 1200 & 12,720 & 8 & 0.101 \\
\hline
\end{tabular}

Ex p e r i m e n t V. Normal rabbit. 1.82 kilos.

The normal amylolytic power of the urine and the normal bloodsugar are determined. Then 5 grms. of pancreatin dissolved in 50 c.c. of water are given per os to the rabbit for eight successive days, and this result is compared with those of the normal rabbit (Table VI).

Table VI.

\begin{tabular}{|c|c|c|c|c|c|c|c|}
\hline \multirow[b]{2}{*}{ Date } & \multicolumn{5}{|c|}{ Urine } & \multicolumn{2}{|c|}{ Blood } \\
\hline & $\mathrm{D}_{30^{\prime}}^{3 \mathrm{a}^{\circ}}$ & $\begin{array}{c}\text { Volume } \\
\text { c.c. }\end{array}$ & $\begin{array}{l}\text { Total } \\
\mathrm{D}_{30^{\prime}}^{38^{\circ}}\end{array}$ & $\begin{array}{c}\text { Tota } \\
\text { D }\end{array}$ & $\begin{array}{l}\text { amount of } \\
\text { for } 8 \text { days }\end{array}$ & $\mathrm{D}_{30^{\prime}}^{3 \mathrm{a}^{\circ}}$ & $\begin{array}{c}\text { Sugar } \\
\%\end{array}$ \\
\hline $\begin{array}{c}\text { June, } 1922 \\
7 \\
8 \\
9 \\
10 \\
11 \\
12 \\
13 \\
14\end{array}$ & $\begin{array}{r}8 \\
16 \\
16 \\
16 \\
8 \\
16 \\
8 \\
16\end{array}$ & $\begin{array}{r}120 \\
125 \\
180 \\
120 \\
125 \\
150 \\
170 \\
90\end{array}$ & $\begin{array}{r}960 \\
2000 \\
2880 \\
1920 \\
1000 \\
2400 \\
1360 \\
1440\end{array}$ & & 13,960 & s & 0.096 \\
\hline $\begin{array}{l}16 \\
17 \\
18 \\
19 \\
20 \\
21 \\
22 \\
23\end{array}$ & $\begin{array}{r}8 \\
8 \\
8 \\
32 \\
16 \\
16 \\
16 \\
8\end{array}$ & $\begin{array}{c}\text { After } \\
210 \\
130 \\
150 \\
120 \\
160 \\
135 \\
135 \\
80\end{array}$ & $\begin{array}{c}\text { g pan } \\
1680 \\
1040 \\
1200 \\
3840 \\
2560 \\
2160 \\
2160 \\
640\end{array}$ & eatin & per os. & 8 & 0.107 \\
\hline
\end{tabular}


The difference between the total diastatic ferment in the urine for eight days before and after giving pancreatin was 1320 , the amount of diastatic ferment in the urine being increased. The total amount of the diastatic ferment of the pancreatin given per os for eight days was 1000. So we see that almost the total amount of the diastatic value given per os was excreted in the urine in eight days.

Experiment VI. Normal rabbit. 1.85 kilos.

After determining the amylolytic power of the normal urine and the normal blood-sugar for ten days, we gave per os to the rabbit 5 grms. of pancreatin dissolved in 50 c.c. of water for the purpose of examining the variation of the amylolytic power and the blood-sugar (Table VII).

TABLE VII.

\begin{tabular}{|c|c|c|c|c|c|c|}
\hline \multirow[b]{2}{*}{ Date } & \multicolumn{4}{|c|}{ Urine } & \multicolumn{2}{|c|}{ Blood } \\
\hline & $\mathrm{D}_{30^{\prime}}^{38^{\circ}}$ & $\begin{array}{l}\text { Volume } \\
\text { c.c. }\end{array}$ & $\begin{array}{l}\text { Total } \\
\mathrm{D}_{30^{\prime}}^{30^{\circ}}\end{array}$ & $\begin{array}{c}\text { Total amount of } \\
D \text { for } 10 \text { days }\end{array}$ & $\mathrm{D}_{30^{\prime}}^{3 \mathrm{8}^{\circ}}$ & $\underset{\%}{\text { Sugar }}$ \\
\hline $\begin{array}{c}\text { June, } 1922 \\
7 \\
8 \\
9 \\
10 \\
11 \\
12 \\
13 \\
14 \\
15 \\
16\end{array}$ & $\begin{array}{r}16 \\
16 \\
16 \\
16 \\
8 \\
16 \\
8 \\
16 \\
16 \\
16\end{array}$ & $\begin{array}{r}75 \\
125 \\
90 \\
90 \\
100 \\
125 \\
140 \\
140 \\
130 \\
90\end{array}$ & $\begin{array}{r}1200 \\
2000 \\
1440 \\
1440 \\
800 \\
2000 \\
1120 \\
2240 \\
2080 \\
1440\end{array}$ & 15,760 & 8 & 0.100 \\
\hline $\begin{array}{c}28 \\
29 \\
30 \\
\text { July } \\
1 \\
2 \\
3 \\
4 \\
5 \\
6 \\
7\end{array}$ & $\begin{array}{r}8 \\
8 \\
8 \\
\\
16 \\
16 \\
16 \\
16 \\
8 \\
16 \\
8\end{array}$ & $\begin{array}{r}180 \\
180 \\
180 \\
120 \\
75 \\
120 \\
150\end{array}$ & $\begin{array}{r}2880 \\
2880 \\
2880 \\
1920 \\
600 \\
1920 \\
1200\end{array}$ & atin per os. & 8 & 0.118 \\
\hline
\end{tabular}

The difference between the total diastatic ferment in the urine before and after giving pancreatin for ten days was 1720, the amount of diastatic ferment in the urine being increased. The total amount of the pancreatin given per os for ten days was 1250 . So the result is that almost the total amount of the diastatic value given per os was excreted in the urine in ten days. The blood-sugar is found to increase slightly. 
Experime $\mathrm{t}$ VII. Normal rabbit. 1.75 kilos.

After we had determined the urine and the blood of the normal rabbit daily for five days, we dissolved 5 grms. of taka-diastase in 50 c.c. of water and gave it per os to the rabbit for five successive days in order to determine the amylolytic power of the urine and the blood-sugar (Table VIII).

TABLE VIII.

\begin{tabular}{|c|c|c|c|c|c|c|}
\hline \multirow[b]{2}{*}{ Date } & \multicolumn{4}{|c|}{ Urine } & \multicolumn{2}{|c|}{ Blood } \\
\hline & $\mathrm{D}_{30^{\prime}}^{38^{\circ}}$ & $\begin{array}{l}\text { Volume } \\
\text { c.c. }\end{array}$ & $\begin{array}{l}\text { Total } \\
\mathrm{D}_{30^{\prime}}^{38^{\circ}}\end{array}$ & $\begin{array}{c}\text { Total amount of } \\
D \text { for } 5 \text { days }\end{array}$ & $\mathrm{D}_{30^{\prime}}^{38^{\circ}}$ & $\underset{\%}{\text { Sugar }}$ \\
\hline $\begin{array}{c}\text { June, } 1922 \\
7 \\
8 \\
9 \\
10 \\
11\end{array}$ & $\begin{array}{r}16 \\
8 \\
16 \\
16 \\
4\end{array}$ & $\begin{array}{r}50 \\
110 \\
120 \\
80 \\
90\end{array}$ & $\begin{array}{r}800 \\
880 \\
1920 \\
1290 \\
360\end{array}$ & 5240 & 8 & 0.103 \\
\hline $\begin{array}{c}28 \\
29 \\
30 \\
\text { July } \\
1 \\
2\end{array}$ & $\begin{array}{r}16 \\
16 \\
16 \\
8 \\
32\end{array}$ & $\begin{array}{c}\text { After } \\
100 \\
100 \\
80 \\
\\
40 \\
80\end{array}$ & $\begin{array}{c}\text { ing tal } \\
1600 \\
1600 \\
1280 \\
\\
320 \\
2560\end{array}$ & -diastase. & 8 & 0.103 \\
\hline
\end{tabular}

The difference between the total diastatic ferment in the urine for five days before and after giving taka-diastase was 2120 , the amount of diastatic ferment in the urine being increased. The total amount of taka-diastase given per os for five days was 6250 . So onethird of the diastatic value given per os was excreted in the urine in five days. The blood-sugar content was almost the same before and after the administration of taka-diastase.

Experiment VIII. Normal rabbit. 1.72 kilos.

After we injected daily for five days 2 c.c. of 1 per cent of pancreatin hypodermically in the back of the normal rabbit, the amylolytic power of the urine and blood-sugar was determined (Table IX).

The difference between the total diastatic ferment in the urine for five days before and after the injection of pancreatin was 320 , the amount of diastatic ferment in the urine being increased. The total amount of the pancreatin injected for five days was 250. Almost the total amount of the diastatic value injected was excreted in the urine in five days. The blood-sugar increased slightly. 
TABLE IX.

\begin{tabular}{|c|c|c|c|c|c|c|}
\hline \multirow[b]{2}{*}{ Date } & \multicolumn{4}{|c|}{ Urine } & \multicolumn{2}{|c|}{ Blood } \\
\hline & $\mathrm{D}_{30^{\prime}}^{38^{\circ}}$ & $\begin{array}{c}\text { Volume } \\
\text { c.c. }\end{array}$ & $\begin{array}{l}\text { Total } \\
\mathrm{D}_{30^{\prime}}^{38^{\circ}}\end{array}$ & $\begin{array}{c}\text { Total amount of } \\
D \text { for } 5 \text { days }\end{array}$ & $\mathrm{D}_{30^{\prime}}^{38^{\circ}}$ & $\underset{\%}{\operatorname{Sugar}}$ \\
\hline July, 1922 & & & & & & \\
\hline 26 & 8 & 110 & 880 & & & 0.103 \\
\hline 27 & 16 & $\begin{array}{l}140 \\
120\end{array}$ & $\begin{array}{r}2240 \\
960\end{array}$ & & & \\
\hline $\begin{array}{l}28 \\
29\end{array}$ & $\begin{array}{r}8 \\
16\end{array}$ & $\begin{array}{l}120 \\
115\end{array}$ & 1840 & & & \\
\hline 30 & 16 & 30 & 480 & 6400 & 8 & 0.101 \\
\hline & & After i & tion o & ancreatin. & & \\
\hline August & & & & & & \\
\hline 4 & 8 & 180 & 1440 & & & \\
\hline 5 & 8 & 110 & 880 & & & \\
\hline 6 & 16 & 160 & 2560 & & & \\
\hline 8 & 8 & 120 & $\begin{array}{l}960 \\
880\end{array}$ & & & \\
\hline 8 & 8 & 110 & 880 & 6720 & 8 & 0.137 \\
\hline
\end{tabular}

Experiment IX. Normal rabbit. 1.82 kilos.

2 c.c. of 1 per cent of taka-diastase were injected hypodermically in the back for five days. Then the urine and the blood were treated in the same way as in Experiment VIII. (Table X.)

TABLE X.

\begin{tabular}{|c|c|c|c|c|c|c|}
\hline \multirow[b]{2}{*}{ Date } & \multicolumn{4}{|c|}{ Urine } & \multicolumn{2}{|c|}{ Blood } \\
\hline & $\mathrm{D}_{30^{\prime}}^{30^{\circ}}$ & $\begin{array}{l}\text { Volume } \\
\text { c.c. }\end{array}$ & $\begin{array}{l}\text { Total } \\
\mathrm{D}_{30^{\prime}}^{3 \circ^{\circ}}\end{array}$ & $\begin{array}{c}\text { Total amount of } \\
\mathrm{D} \text { for } 5 \text { days }\end{array}$ & $\mathrm{D}_{30^{\prime}}^{38^{\circ}}$ & Sugar \\
\hline $\begin{array}{c}\text { July, } 1922 \\
6 \\
7 \\
8 \\
9 \\
10\end{array}$ & $\begin{array}{l}4 \\
4 \\
4 \\
4 \\
4\end{array}$ & $\begin{array}{r}46 \\
94 \\
85 \\
104 \\
156\end{array}$ & $\begin{array}{l}184 \\
376 \\
340 \\
416 \\
624\end{array}$ & 1940 & 8 & $\begin{array}{l}0.100 \\
0.101\end{array}$ \\
\hline $\begin{array}{l}12 \\
13 \\
14 \\
15 \\
16\end{array}$ & $\begin{array}{l}8 \\
8 \\
4 \\
4 \\
4\end{array}$ & $\begin{array}{c}\text { After in } \\
30 \\
145 \\
170 \\
140 \\
140\end{array}$ & $\begin{array}{r}\text { ion of } \\
240 \\
1160 \\
680 \\
560 \\
560\end{array}$ & ka-diastase. & 8 & 0.105 \\
\hline
\end{tabular}

The difference between the total diastatic ferment in the urine for five days before and after the injection of taka-diastase was 1260, the amount of diastatic ferment in the urine being increased. The total amount of taka-diastase injected for five days was 2500 . So about half of the. total amount of the diastatic value injected was excreted in the urine in five days. 
Experime $\mathrm{n}$ X. Normal rabbit. 1.69 kilos.

On five successive days 2 c.c. of 1 per cent of taka-diastase were injected hypodermically in the back of the rabbit and the amylolytic power of the urine and the blood-sugar of the rabbit was determined with a view to comparing it with those of the normal rabbit before the injection (Table $\mathrm{XI}$ ).

TABLE XI.

\begin{tabular}{|c|c|c|c|c|c|c|}
\hline \multirow[b]{2}{*}{ Date } & \multicolumn{4}{|c|}{ Urine } & \multicolumn{2}{|c|}{ Blood } \\
\hline & $\mathrm{D}_{30^{\prime}}^{38^{\circ}}$ & $\begin{array}{c}\text { Volume } \\
\text { c.c. }\end{array}$ & $\begin{array}{l}\text { Total } \\
\mathrm{D}_{30^{\prime}}^{38^{\circ}}\end{array}$ & $\begin{array}{c}\text { Total amount of } \\
\text { D for } 5 \text { days }\end{array}$ & $D_{30^{\prime}}^{38^{\circ}}$ & $\underset{\%}{\operatorname{Sugar}}$ \\
\hline $\begin{array}{c}\text { July, } 1922 \\
6 \\
7 \\
8 \\
9 \\
10\end{array}$ & $\begin{array}{l}4 \\
4 \\
4 \\
4 \\
4\end{array}$ & $\begin{array}{l}108 \\
112 \\
117 \\
120 \\
120\end{array}$ & $\begin{array}{l}432 \\
.448 \\
468 \\
480 \\
480\end{array}$ & 2308 & 8 & $\begin{array}{l}0.108 \\
0.108\end{array}$ \\
\hline $\begin{array}{l}12 \\
13 \\
14 \\
15 \\
16\end{array}$ & $\begin{array}{r}16 \\
8 \\
4 \\
4 \\
4\end{array}$ & $\begin{array}{c}\text { After in } \\
44 \\
100 \\
125 \\
130 \\
170\end{array}$ & $\begin{array}{r}\text { ion of } \\
704 \\
800 \\
500 \\
520 \\
680\end{array}$ & ka-diastase. & 8 & 0.03 \\
\hline
\end{tabular}

The difference between the total diastatic ferment in the urine for five days before and after giving taka-diastase for five days was 896 , the amount of diastatic ferment in the urine being increased. The total amount of taka-diastase given hypodermically for five days was 2500. About one-half of the diastatic value given hypodermically was excreted in the urine in five days. From the above researches I learned that the diastatic ferment increased in the urine by almost the total amount of the given diastatic value when pancreatin was administered per os and when it was injected hypodermically. Moreover when taka-diastase was given per os the diastatic ferment was found to increase by one-half of the given diastatic value in the urine. But when it was given hypodermically almost all the injected amylase was excreted in the urine.

\section{Conclusions.}

(1) The value of the diastatic ferment, i. e. amylase, varies from time to time in the course of a day; and the total amount of the same ferment excreted in a day does not remain constant.

(2) Whenever the amylolytic ferment is introduced into the 
hody, whether per os or injected hypodermically, the amount of the same ferment increases in the urine.

(3) The level of the amylolytic ferment in the blood-serum always remains constant. The amount of the same ferment determined in the serum shows the nearest or rather the same value whether this ferment is given per os or hypodermically.

(4) The blood-sugar content was found to increase slightly whenever pancreatin was given either per os or hypodermically.

\section{ReFERENCES.}

(1) Cohnheim: Virchow's Arch. f. path. Anat. u. Physiol., 1863, 28, 241.

(2) M a g e $\mathrm{n}$ di e: Comptes rendus d. 1. Soc. d. Biol., 1846, 23, 189.

(3) Wo h lg e m u th: Biochem. Ztschr., 1908, 9, 1.

(4) Wo h lg e m u th: Biochem. Ztschr., 1909, 21, 381.

(5) Wo h lg e m u th: Berl. klin. Woch., 1910, 47, 1444.

(6) B e n c z u r: Wien. klin. Woch., 1910, 23, 890.

(7) W y n h a u s e n: Berl. klin. Woch., 1909, 46, 1406; 1910, 47, 2107.

(8) Rosenthal: Dtsch. med. Woch., 1911, 37, 923.

(9) M a rin o: Dtsch. Arch. f. kl. Med., 1911, 103, 325. 722.

(10) L o e per and Fi ça i: Arch. d. méd. exp. et d'anat. pathol., 1907, 19,

(11) Kussmaul: Dtsch. Arch. f. kl. Med., 1874, 14, 1. 